\title{
Defining the Scope of Alexandre Dumas's La Drame De La France: Problems, Considerations, and Debates
}

\author{
Eric Martone \\ Mercy College
}

\begin{abstract}
Alexandre Dumas's interment in the Panthéon in 2002 prompted a steady reevaluation of his literary reputation, resulting in his increased prominence among his nineteenth-century peers. Several studies have resurrected Dumas's 1857 argument that his works comprise a vast series entitled La Drame de la France. This argument has become so ubiquitous that it has become an uncontested fact. However, there are certain challenges in studying Dumas's La Drame de la France. Dumas did not repeatedly make this assertion, which was announced toward the latter portion of his life, and whether it was something that consciously and continuously drove his plans when developing future ideas and concepts for his historical fiction novels is debatable. Therefore, while not disputing the existence of La Drame de la France, its nature (and the nature of its creation) nevertheless makes it so that which novels specifically comprise it has never been definitively established. Coming to some degree of consensus on this point is needed as a first step to advance studies of Dumas in this area. This article seeks to initiate this literary discussion by presenting Dumas's 36 major historical fiction novels set in France, briefly examining the problems, considerations, and debates that exist in whether each could be accepted as part of the series.
\end{abstract}

Keywords: Alexandre Dumas, La Drame de la France, Musketeers, Monte Cristo, feuilleton

\section{Introduction}

Alexandre Dumas's interment in the Panthéon in 2002 prompted a steady reevaluation of his literary reputation, resulting in his increased prominence among his nineteenth-century peers. ${ }^{1}$ Such high reevaluations, spurred by changing conceptions of French identity and

\footnotetext{
1 Since that time, several collections of Dumas scholarship have appeared. Examples: Michel Arrous, ed., Dumas, une lecture de l'histoire (Paris: Maisonneuve and Larose, 2003); Angels Santa and Francisco Lafarga, eds., Alexandre Dumas y Victor Hugo: Viaje de los textos y textos de viaje (Lleida: Pagès Editors, 2006); Chantal Massol, ed., Stendhal, Balzac, Dumas: Un récit romantique? (Toulouse: Presses Universitaires du Mirail, 2006); Charles Grivel, ed., Les Vies parallèles d'Alexandre Dumas (Villeneuve d'Ascq: Presses Universitaires du Septentrion/Revue des Sciences humaines, 2008); Pascal Durand and Sarah Mombert, eds., Entre presse et littérature: Le Mousquetaire, journal de M. Alexandre Dumas (Liège: Bibliothèque de la Faculté de Philosophie et Lettres, Diffusion Droz, 2009); Eric Martone, ed., The Black Musketeer: Reevaluating Alexandre Dumas within the Francophone World (Newcastleupon-Tyne: Cambridge Scholars, 2011); Julie Anselmini, ed., Dumas Critique (Limoges: Presses
} 
culture, would have surprised critics just half a century earlier. ${ }^{1}$ As Dumas's biographer A. Craig Bell noted in 1950, "Dumas is a river which academicians, critics and literary snobs have been fouling for half a century" (ix). However, such a view was not new. As early as 1848, literary critics in Dumas's lifetime, like Charles Robin, declared that Dumas "a été, a lui seul, l'objet de plus d'interprétations de toute nature et de discussions littéraire que tous les écrivains du XIXe siècle" (137). ${ }^{2}$ The situation had not changed much by 1885 , when Henri Blaze de Bury confessed, "Dumas est populaire, il n'est pas connu. Son genre de vie, ici et là quelques méchants volumes qu'il eût mieux fait de ne pas écrire, ont beaucoup nui à sa considération littéraire. On le prend généralement pour un simple amuseur, et cependant, toute comme un autre et plus qu'un autre, il a ses heures d'élévation et de philosophie" (47; original emphasis). ${ }^{3}$

During his lifetime, Dumas faced opposition from certain intellectuals because of his interest in pursuing commercial literary ambitions, accusations of establishing a "writing factory" in which he placed his name on works composed by others, and his status as an individual of mixed racial descent. ${ }^{4}$ Following Dumas's death in 1870, literary scholars have put forward several reasons to account for the lack of studies of Dumas, despite his popularity. In the 1990s, for example, Dorothy Trench-Bonett described several common reasons to account for this during the twentieth century. She placed particular emphasis on Dumas's voluminous literary output, which makes him difficult to study. ${ }^{5}$ Nineteenth-century critic Joseph Marie Quérard was overly critical of Dumas, particularly in his five-volume Les Supercheries littéraires dévoilées, largely for this reason. As journalist Philibert Audebrand wrote satirically in 1888, Dumas had written so much that "quand le vieux Quérard, ce bénédictin de notre âge, essayant de dresser l'inventaire des richesses bibliographiques du pays," reached Dumas's name, "il ne put se défendre d'un léger frisson d'effroi. La seule nomenclature des œuvres de ce géant faisant vaciller ses regards. Comment un tel homme avait-il pu venir à bout d'une telle tâche? A la vérité, il expliquait que quatre-vingt-douze collaborateurs avaient coopéré à l'éclosion de tant de choses" (3-4). ${ }^{6}$

universitaires de Limoges, 2013); Eric Martone, ed., Alexandre Dumas as a French Symbol since 1870: All for One and One for All in a Global France (Newcastle-upon-Tyne: Cambridge Scholars, 2020). ${ }^{1}$ For Dumas's shifting status as a symbol of contemporary France, see: Roxane Petit-Rasselle, "From the Literary Myth to the Lieu de Mémoire-Alexandre Dumas and French National Identity(ies)," in Alexandre Dumas as a French Symbol since 1870: All for One and One for All in a Global France, 89117; Eric Martone, Finding Monte Cristo: Alexandre Dumas and the French Atlantic World (Jefferson, NC: McFarland, 2018), 111-149.

2 English translation: Dumas "has been the subject of more interpretations, true and false, and of more literary battles than any other writer of the nineteenth century."

3 English translation: "Dumas is popular, but he is not recognized. His method of life and his occasional worthless books greatly damaged his literary position. He is usually looked upon simply as an 'amuser,' and yet... more than many others, he had his moments of lofty thought and philosophy."

${ }^{4}$ See: Martone, Finding Monte Cristo, 13-49.

5 Other reasons include Dumas's popularity, which has been held against him as a serious writer; Dumas's colorful life, which often sidetracks those attempting to study him; and Dumas's status as a writer for young people, which had led critics to underestimate the complexity of his works. See: Dorothy Trench-Bonett, "Alexandre Dumas: Black French Writer," in Alexandre Dumas, Charles VII at the Home of His Vassals, trans. Dorothy Trench-Bonett (New York: Noble Press, 1991), 26-27. ${ }^{6}$ English translation: "when old Quérard, that benedictine of our age, tried to take an inventory of the rich bibliography of the country, when he arrived at... [Dumas's] name, he could barely refrain from a 
To help make Dumas's work more manageable for study, and in particular his historical fiction novels, many recent literary scholars have resurrected Dumas's argument that his works comprise a vast series entitled La Drame de la France. Dumas made this claim in 1857 in chapter XLIV in his historical novel, Les Compagnons de Jéhu:

Peut-être ceux qui lisent chacun de nos livres isolément s'étonnent-ils que nous appuyions parfois sur certains détails qui semblent un peu étendus pour le livre même dans lequel ils se trouvent. C'est que nous ne faisons pas un livre isolé; mais... nous remplissons ou nous essayons de remplir un cadre immense. Pour nous, la présence de nos personnages n'est point limitée à l'apparition qu'ils font dans un livre : celui que vous voyez aide de camp dans cet ouvrage, vous le retrouverez roi dans une second, proscrit et fusillé dans un troisième. Balzac a fait une grande et belle œuvre à cent faces, intitulée La Comédie humaine. Notre œuvre à nous, commencée en même temps que la sienne, mais que nous ne qualifions pas, bien entendu, peut s'intituler La Drame de la France (III, 83-84). ${ }^{1}$

Indeed, in the decades after Dumas's death in 1870, many French intellectuals commented on how Dumas's novels taught generations of Frenchmen the history of the nation. ${ }^{2}$ In La Comédie littéraire (1895), for example, Adolphe Brisson devoted a chapter to Dumas and history, presenting the writer as a great chronicler of the dramatic story of "France" (213-226). In 1902, the critic Georges Pellissier declared there was an entire classroom contained within Dumas's works (232). Consequently, as French intellectual André Maurois declared in the 1950s, "it should be added that the world at large-and France in particular-has learned French history in the pages of Dumas" (183).

However, there are certain obstacles in studying Dumas's La Drame de la France, the most significant of which is its ill-defined scope, sequence, and unifying themes. Claude Schopp, possibly the most influential contemporary French scholar on Dumas, has been one of the chief advocates that Dumas's novels comprise such a series, which has been positioned as serving as a prequel series to that of Honoré de Balzac's La Comédie humaine, set during the Restoration (1815-1830) and July Monarchy (1830-1848) and Émile Zola's Les RougonMacquart, set during the final days of the Second Republic (1848-1852) and the span of the Second French Empire (1852-1870). ${ }^{3}$ Such an association in itself elevates Dumas's literary

slight shudder of fear. The very name on the works of this giant weakened his resolve. How could one man undertake such a task? In truth, he explained that 92 collaborators had cooperated to the realization of so many works."

1 English translation: "Perhaps those who read our books singly are surprised that we sometimes dwell on certain details which seem somewhat long drawn for the book in which they appear. The fact is, we are not writing isolated books, but, as we have already said, we are filling, or trying to fill, an immense frame. To us, the presence of our characters is not limited to their appearance in one book. The man you meet in one book may be a king in a second volume, and exiled or shot in a third. Balzac did a great and noble work with a hundred aspects, and he called it the Comédie Humaine. Our work, begun at the same time as his...may fitly be called The Drama of France. See: Alexandre Dumas, "Chapter XLIV: Change of Residence," The Companions of Jehu, trans. (New York: P.F. Collier and Son, n.d.), 482.

2 For overview, see: Eric Martone, "All for One and One for All: Recasting Alexandre Dumas as a Popular Educator in France during the New Imperialism," Global Education Review 6, 4 (2019): 50-79.

3 See: Claude Schopp, "Le fil de l'Histoire," Le Figaro (hors-série): Alexandre Dumas, Au galop des mousquetaires (2002), 66; Claude Schopp, "Le Testament perdu," in Alexandre Dumas, Le Chevalier de Sainte-Hermine (Paris: Phébus, 2005), 47-49; Claude Schopp, Dictionnaire Dumas (Paris: CNRS Éditions, 2010), 266-270. See also: Youjun Peng, La nation chez Alexandre Dumas (Paris: L'Harmattan, 
status, as both Balzac and Zola remain among the most studied and highly-regarded figures in nineteenth-century French literature. ${ }^{1}$ Dumas's reevaluation, and Schopp's influence in particular, has made this argument so ubiquitous that it has become an uncontested fact.

Yet Dumas did not repeatedly make this assertion, announced toward the latter portion of his life, and whether it was something that consciously and continuously drove his plans when developing future ideas and concepts for his historical fiction novels is debatable. Dumas did not always flesh out beforehand the events within his individual novels, never mind a whole "series" composed over decades. He is infamous for changing character's names or details midtory, as he generally published his novels initially in serial form, often composing several novels at once. ${ }^{2}$ As a result, the critic Ferdinand Brunetière wrote that Dumas's dramatic works "ne sont pas littéraires. Ils n'ont pas de style, et la forme y reste indécise, imprécise, banale. La psychologie y est sans profondeur. Ils sont mal composés. La vie de l'homme explique ce caractère de son œuvre" (IV, 247). Dumas's novels, he argued, possess "certaines qualités littéraires," but they are "romans industriels" hastily composed (IV, 261). ${ }^{3}$ Consequently, Dumas's conception of his historical fiction novels forming a composite and collective series was at best a loose, retrospective reflection on his body of work. Therefore, while I do not wish to dispute the existence of La Drame de la France, its nature (and nature of its creation) makes it so that the novels that specifically comprise it has never been definitively established. Coming to some degree of consensus on this point is needed as a first step to advance studies of Dumas in this area, as well as make comparatives studies between Dumas and other writers and series. This article seeks to initiate this literary discussion by presenting Dumas's 36 major historical fiction novels set in France, briefly examining the problems, considerations, and debates that exist in whether each should be accepted as part of the series (in comparison, La Comédie humaine consists of 91 finished works and Les Rougon-Macquart consists of 20 novels). ${ }^{4}$ Guiding this discussion are four criteria: Dumas's conception of French

2003); Jean Tulard, Alexandre Dumas, 1802-1870 (Paris: Figures et plumes, 2008), 74-76; Anne-Marie Callet-Bianco, "Un projet romantique: la quête de la totalité chez Balzac et Dumas " in Stendhal, Balzac, Dumas: un récit romantique, eds. Lise Dumasy, Chatal Massol, and Marie-Rose Corredor (Toulouse: Presses universitaires du Mirail, 2006), 53-67.

${ }^{1}$ For example, Nineteenth-Century French Studies published barely a dozen articles on Dumas from 1972 to 2010. In comparison, during the same period, Zola was the subject about 80 articles; Balzac was the subject of nearly 90 articles.

2 For example, in Le Château d'Eppstein (1843), the character Maximilian states that his wife's name was Thecla in the beginning of the novel, but later states her name was Bertha. Another example occurs in Le Volontaire de ' 92 (1862) when the main protagonist, René, references an event toward the end of the novel in which he helped Sophie and the Viscount de Malmy escape that was never described previously.

3 English translation: Brunetière wrote that Dumas's dramatic works "are not literature. They have no style and the form remains indecisive, imprecise, and banal. The psychology found in his work is without depth. They are poorly composed. The life of the man explains the character of his work." Dumas's novels, he argued, possess "literary qualities," but they are "industrial novels" hastily composed.

${ }^{4}$ Major novels set during Dumas's present-day France (predominantly during the July Monarchy) lacking a strong historical focus-and thus omitted from consideration-include: Amaury (1843), set 1838-1839; Catherine Blum (1854), set during 1829-1830; Le Chasseur de sauvagine (1859), set during 1818-1841; Fernande (1844), set in 1835; Le Fils du forçat (1860), set during 1831-1845; Les Drames galants; La marquise d'Escoman (1860), set during 1831-1840; Madame de Chamblay (1859), set in 1836-1856; Parisiens et provinciaux (1868), set in 1846; Le Père la Ruine (1860), set during 
history, the significance of specific historical figures within the novel's plots, shared characters among multiple novels, and the significance the novel has traditionally held within studies on Dumas's work.

\section{Dumas's Conception of French History}

For a sequence books to comprise a series, there must be some common characteristics or unifying threads that can formally unite them. In nineteenth-century France, the rise of the extended serial novel, published in cliffhanger installments in newspapers, encouraged the practice of a novel sequence. A novel sequence is a specific type of series in which the novels it includes may contain some common elements (such as themes, setting, or characters), but each individual novel can stand of its own (i.e., it has its own title, unique plot, etc.). As such, each novel can be read in, or out, of the sequence. Consequently, a novel sequence may encompass multiple story arcs or themes that span several books instead of including one or more common characters. The novel sequence had been popularized earlier in the century through the works of such writers as Fenimore Cooper in the 1820s. In French literature, the previously mentioned series by Balzac (La Comédie humaine) and Zola (Les Rougon-Macquart) are also nineteenth-century novel sequences, although there are many others. Dumas's work and conception of a series of historical novels was also likely influenced by Sir Walter Scott (1771-1832). Scott's major series (The Waverley Novels), as in the case of Dumas, include subseries (Tales of my Landlord, Tales of the Crusaders, Chronicles of the Canongate) that span broad historical epochs and are largely independent of each other, and thus only loosely connected. ${ }^{1}$

Around 1822, when Dumas was only about 20 years old, he demonstrated his fascination with the British writer's work by drafting a three-act dramatization of Scott's Ivanhoe as one of his earliest literary efforts. Balzac's pragmatic series, which was also conceived after the publication of several of its novels, is more open and extendable than Zola's predetermined series, organized around an extended family group. Dumas's conception of a series is thus theoretically closer to Balzac's than Zola's. However, both Balzac's and Zola's series focused on shorter historical periods and are joined through the reappearance of several fictional characters. Scott's novels, on the other hand, span an extended chronological spectrum and are largely independent of each other, and therefore not associated with each other in any strict sense.

Dumas's conception of history is largely the unifying, overarching theme of La Drame de la France, which, as a novel sequence, covers an extended chronological spectrum. Dumas's view of history is revealed in his Gaul et France (1833), which regarded the spreading of democracy as synonymous with progress. Among the first of Dumas's many historical works, the original edition included an epilogue, omitted from later printings, in which Dumas foretold the reestablishment of the Republic. However, a prologue from his novel The Comtesse de Salisbury (1839), which chronicles part of the Hundred Years' War, was later added. An anonymous

1794-1834; and Gabriel Lambert (1844), set in 1831-1842. Dumas's historical fiction novellas/short stories set in France are also omitted. These works include: Blanche de Beaulieu, ou la vendéene (1826), set in 1793-1794; Cécile (1844), set in 1792-1805; Les Frères corses (1844), set in 1841; and Monseigneur Gaston Phoebus (1839), set in 1385-1391.

1 See: J.H. Alexander, Walter Scott's Books: Reading the Waverley Novels (New York: Routledge, 2017); Aude Déruelle, "Dumas et Balzac," in L'Herne: Dumas, eds. Sylvain Ledda and Claude Schopp (Paris: L’Herne, 2020), pp. 117-118. 
English translation appeared in 1841 under the title of The Progress of Democracy; illustrated in the History of Gaul and France, including all elements of the work.

Following a brief introduction, Gaule et France is divided into three parts tracing French history from ancient time to 1328 (the Franco-Roman monarchy, covering events up to Pepin the Short; the Frank monarchy, covering events from Pepin the Short to Hugh Capet; and the French monarchy, covering events from Hugh Capet to Philippe de Valois) and a conclusion. The conclusion not only summarizes the first three parts, but also serves as an epilogue following French history from the medieval period to Dumas's present. Based on the different kinds of territorial properties that existed through centuries (like feudalism, seigneury, aristocracy, and private property), Dumas separates history into four periods and perceives events as part of a divinely guided mission toward a republic, which was viewed as France's destiny.

Some have argued that such a theme unites Dumas's historical fiction, which sought to map this progress to his nineteenth-century present. Regardless of whether Dumas intentionally sought to establish a sweeping La Drame de la France from the beginning of his literary efforts, the conceptions of history he articulated before and near the beginning of his efforts writing historical fiction novels inevitably created a loose, overarching framework for how he viewed the past and how the past culminated in his present; such conceptions thus form the unifying theme of Dumas's larger novel sequence. Further, the concept of creating La Drame de la France likely did influence the works he wrote from 1857 until his death in 1870. Dumas did compose various smaller cycles of novels, or subseries, covering more compact sequences of historical events. As a result, these well-known cycles have been incorporated into La Drame de la France. These cycles can be more tightly united through the reappearance of fictional characters (as the case in his Musketeers cycle and Saint-Hermine cycle), by the reappearance of historical figures (such as in his Valois cycle and Regency cycle), or both.

The Mémoires d'un médecin pentalogy is united uniquely by reappearing fictional and historical characters in the first four novels, whereas the fifth novel in the series - Le Chevalier de Maison-Rouge-is connected only through the reappearance of historical characters. Further, all novels in a cycle are typically united by the historical period in which events occur (such as sixteenth-century France). However, within the broader novel sequence of La Drame de la France, as Schopp has argued, Dumas's Valois cycle (La Reine Margot, La Dame de Monsoreau, Les Quarante-cinq) relates the seigneury's decadence, and his Musketeers cycle corresponds with the seigneury's demise and the aristocracy's ascent. The end of the aristocracy is related in the Mémoires d'un médecin cycle (Mémoires d'un médecin: Joseph Balsamo, Le Collier de la Reine, Ange Pitou, La Comtesse de Charny, and Le Chevalier de MaisonRouge). The passage to the future republic begins in his Saint-Hermine cycle (Les Blancs et les Bleus, Les Compagnons de Jéhu, and Hector de Saint-Hermine). Le Comte de Monte Cristo marks the culmination of Dumas's series of novels. ${ }^{1}$ However, while the inclusion of such novels is not disputed, there are various other historical fiction novels that merit consideration, as they relate to and enhance both this sweeping understanding of French history and La Drame de la France.

${ }^{1}$ He makes such arguments in: Schopp, Dictionnaire Dumas, 268; Schopp, “Le Testament perdu," 47-49. 


\section{Dumas's Works of Historical Fiction Covering French History}

Table 1: Dumas's La Drame de la France (In the chart below, the novels in white boxes represent those in which wide agreement exists to place them as part of Dumas's extended series. Those in light gray boxes represent novels with strong arguments for inclusion, while those in dark gray boxes represent novels with weaker arguments for inclusion.)

\begin{tabular}{|c|c|c|}
\hline Ascanio & 1843 & $\begin{array}{l}\text { Artist Benvenuto Cellini's tenure at the French } \\
\text { court of François I (circa } 1539 \text { to 1545) }\end{array}$ \\
\hline Les Deux Diane & 1846-1847 & $\begin{array}{l}\text { The taking of Calais, the battle of Saint-Quentin, } \\
\text { Henri II's death, and the Wars of Religion (circa } \\
\text { 1521-1574) }\end{array}$ \\
\hline $\begin{array}{l}\text { Le Page du duc de } \\
\text { Savoie }\end{array}$ & 1855 & $\begin{array}{l}\text { Account of Emmanuel Philibert, Duke of Savoy, } \\
\text { who defeats Henri II in warfare, and then makes } \\
\text { accord with him. Covers the end of Henri II's reign, } \\
\text { including the battle of Saint-Quentin, the peace of } \\
\text { Cateau-Cambrésis, and king's death from a jousting } \\
\text { accident (circa 1528-1580) }\end{array}$ \\
\hline L'Horoscope & 1858 & François II's reign, circa 1559 \\
\hline $\begin{array}{l}\text { La Reine Margot } \\
\text { (Valois Cycle) }\end{array}$ & 1845 & $\begin{array}{l}\text { Marguerite de Valois and Henri of Navarre's } \\
\text { marriage, the St. Bartholomew's Day Massacre, and } \\
\text { Charles IX's reign (circa 1572-1574) }\end{array}$ \\
\hline $\begin{array}{l}\text { La Dame de } \\
\text { Monsoreau } \\
\text { (Valois Cycle) }\end{array}$ & 1845 & Henri III's reign, circa 1578-1579 \\
\hline $\begin{array}{l}\text { Les Quarante-Cinq } \\
\text { (Valois Cycle) }\end{array}$ & 1847 & Henri III's reign, circa 1584-1585 \\
\hline $\begin{array}{l}\text { Les Trois } \\
\text { Mousquetaires } \\
\text { (Musketeers Cycle) }\end{array}$ & 1844 & $\begin{array}{l}\text { The solidification of the Bourbon dynasty through } \\
\text { Louis XIII's reign, circa } 1625-1628\end{array}$ \\
\hline $\begin{array}{l}\text { Le Comte de Moret; } \\
\text { Le Sphinx Rouge }\end{array}$ & $1865-1866$ & $\begin{array}{l}\text { The last years of Cardinal Richelieu's control over } \\
\text { France (circa 1628-1630). Features Antoine de } \\
\text { Bourbon, Come de Moret, the illegitimate son of } \\
\text { Henri IV as a main protagonist. }\end{array}$ \\
\hline La Colombe & 1851 & $\begin{array}{l}\text { The Comte de Moret's mysterious disappearance } \\
\text { after the battle of Castelnaudary (circa 1637-1638) }\end{array}$ \\
\hline $\begin{array}{l}\text { Vingt Ans après } \\
\text { (Musketeers Cycle) }\end{array}$ & 1845 & $\begin{array}{l}\text { Set after Louis XIII's death when Anne of Austria, } \\
\text { assisted by Cardinal Mazarin, governed France on } \\
\text { behalf of young Louis XIV (circa 1648-1649) }\end{array}$ \\
\hline $\begin{array}{l}\text { La Guerre des } \\
\text { femmes }\end{array}$ & 1844-1846 & The Fronde, during Louis XIV's reign (circa 1650) \\
\hline $\begin{array}{l}\text { Le Vicomte de } \\
\text { Bragelonne, ou Dix } \\
\text { ans plus tard } \\
\text { (Musketeers Cycle) }\end{array}$ & 1848-1850 & Louis XIV's reign, circa $1660-1673$ \\
\hline Sylvandire & 1843 & $\begin{array}{l}\text { End of Louis XIV's reign and death, circa 1708- } \\
1716\end{array}$ \\
\hline
\end{tabular}




\begin{tabular}{|c|c|c|}
\hline $\begin{array}{l}\text { Le Chevalier } \\
\text { d'Harmental } \\
\text { (Regency Cycle) }\end{array}$ & 1842 & $\begin{array}{l}\text { Cellamare Conspiracy against Philippe d'Orléans, } \\
\text { regent for the young Louis XV (circa 1718) }\end{array}$ \\
\hline $\begin{array}{l}\text { Une Fille du Régent } \\
\text { (Regency Cycle) }\end{array}$ & 1844 & The Cellamare Conspiracy's aftermath (circa 1719) \\
\hline Olympe de Clèves & 1852 & Louis XV's reign, circa 1727-1729 \\
\hline $\begin{array}{l}\text { Mémoires d'un } \\
\text { médecin: Joseph } \\
\text { Balsamo } \\
\text { (Mémoires d'un } \\
\text { médecin Cycle) }\end{array}$ & 1846-1848 & $\begin{array}{l}\text { The end of Louis XV's reign, Count Cagliostro, and } \\
\text { the marriage of Marie Antoinette and future Louis } \\
\text { XVI (circa 1770-1774) }\end{array}$ \\
\hline Le Meneur de loups & 1857 & The French countryside, circa 1780 \\
\hline $\begin{array}{l}\text { Le Collier de la } \\
\text { Reine } \\
\text { (Mémoires d'un } \\
\text { médecin Cycle) }\end{array}$ & 1849-1850 & $\begin{array}{l}\text { The Affair of the Diamond Necklace and the } \\
\text { ensuing backlash against Queen Marie Antoinette } \\
\text { and the French monarchy (circa 1784-1785) }\end{array}$ \\
\hline $\begin{array}{l}\text { Création et } \\
\text { Rédemption }\end{array}$ & 1872 & $\begin{array}{l}\text { Adventures of a doctor and young girl during the } \\
\text { onset of the French Revolution (circa 1785-1794) }\end{array}$ \\
\hline Ingénue & 1854 & Onset of the French Revolution, circa 1788-1793 \\
\hline $\begin{array}{l}\text { Ange Pitou } \\
\text { (Mémoires d'un } \\
\text { médecin Cycle) }\end{array}$ & 1853 & Onset of the French Revolution, circa 1789 \\
\hline $\begin{array}{l}\text { Le Volontaire de } \\
\text { '92; René } \\
\text { d'Argonne, René } \\
\text { Besson: un témoin } \\
\text { de la Révolution }\end{array}$ & 1862 & Onset of the French Revolution, circa 1788-1793 \\
\hline $\begin{array}{l}\text { La Comtesse de } \\
\text { Charny } \\
\text { (Mémoires d'un } \\
\text { médecin Cycle) }\end{array}$ & 1853-1855 & $\begin{array}{l}\text { The French Revolution and Louis XVI's execution } \\
\text { (circa 1789-1793) }\end{array}$ \\
\hline $\begin{array}{l}\text { Le Chevalier de } \\
\text { Maison-Rouge } \\
\text { (Mémoires d'un } \\
\text { médecin Cycle) }\end{array}$ & 1845 & $\begin{array}{l}\text { The French Revolution, particularly the rescue of } \\
\text { Marie Antoinette from the Temple (circa 1793) }\end{array}$ \\
\hline $\begin{array}{l}\text { Les Blancs et les } \\
\text { Bleus } \\
\text { (Sainte-Hermine } \\
\text { Cycle) }\end{array}$ & 1867-1868 & $\begin{array}{l}\text { The final years of the French Revolution- } \\
\text { including the Reign of Terror, the Convention, and } \\
\text { the Directory-and the rise of Napoléon (circa } \\
\text { 1793-1799) }\end{array}$ \\
\hline $\begin{array}{l}\text { Les Compagnons de } \\
\text { Jéhu } \\
\text { (Sainte-Hermine } \\
\text { Cycle) }\end{array}$ & 1857 & $\begin{array}{l}\text { Napoléon as First Consul, Royalist resistance to } \\
\text { Napoléon, and Napoléon's triumph (circa 1799- } \\
\text { 1800) }\end{array}$ \\
\hline $\begin{array}{l}\text { Le Chevalier de } \\
\text { Sainte-Hermine } \\
\text { (Sainte-Hermine } \\
\text { Cycle) }\end{array}$ & 2005 & $\begin{array}{l}\text { The rise of the First French Empire under } \\
\text { Napoléon (circa 1800-1809) }\end{array}$ \\
\hline
\end{tabular}




\begin{tabular}{|c|c|c|}
\hline $\begin{array}{l}\text { Le Salut de l'Empire } \\
\text { (Sainte-Hermine } \\
\text { Cycle) }\end{array}$ & 2008 & $\begin{array}{l}\text { The closing years of the First French Empire, } \\
\text { including Napoléon's retreat from Moscow and the } \\
\text { Battle of Leipzig, Napoléon's exile to Elba, the } \\
\text { Restoration, and Napoléon's 100 Days and the } \\
\text { battle of Waterloo (circa 1808-1815) }\end{array}$ \\
\hline $\begin{array}{l}\text { Le Capitaine } \\
\text { Richard }\end{array}$ & 1858 & $\begin{array}{l}\text { The closing years of the First French Empire, } \\
\text { especially Napoléon's retreat from Moscow (circa } \\
\text { 1809-1815) }\end{array}$ \\
\hline $\begin{array}{l}\text { Conscience } \\
\text { l'innocent }\end{array}$ & 1853 & $\begin{array}{l}\text { An adventure set in the later years of Napoléon's } \\
\text { reign and Waterloo (circa 1810-1815) }\end{array}$ \\
\hline Georges & 1843 & French colonies (circa 1810-1824) \\
\hline $\begin{array}{l}\text { Les Mohicans de } \\
\text { Paris }\end{array}$ & 1854-1859 & Restoration Era from $1820-1830$ \\
\hline $\begin{array}{l}\text { Les Louves de } \\
\text { Machecoul }\end{array}$ & 1859 & $\begin{array}{l}\text { The Restoration Era, July Revolution, and } 1832 \\
\text { royalist uprising in the Vendée (circa 1793-1843) }\end{array}$ \\
\hline $\begin{array}{l}\text { Le Comte de Monte } \\
\text { Cristo }\end{array}$ & $1845-1846$ & $\begin{array}{l}\text { Restoration Era, Napoléon's exile on Elba and his } \\
100 \text { Days, Return of the Bourbon monarchy, and } \\
\text { July Monarchy (circa 1815-1838) }\end{array}$ \\
\hline
\end{tabular}

\section{French Renaissance (circa 1521-1580)}

The earliest setting for Dumas's major French historical fiction novels is during the reign of François I and the birth of the French Renaissance. The first of these novels, Ascanio (1843), depicts artist Benvenuto Cellini's residence at the court of François I during the years 1539 to 1545. Ultimately, the novel provides a reflection on the relationship between the aristocracy of talent and that of birth, which helps set up Dumas's conceptions of French history and its destiny to become a republic that serve to unify La Drame de la France. Several minor characters who appear in Ascanio (1843) have cameos in two subsequent works: Les Deux Diane (1846-1847) and Le Page du duc de Savoie (1855). Due to their reappearance, these novels are often viewed as forming a loose trilogy. Les Deux Diane (1846-1847), covering events from 1521 to 1574, focuses primarily on the events of the reign of François I's son, Henri II (such as the taking of Calais, the battle of Saint-Quentin, Henri II's death, and the Wars of Religion). A third novel, Le Page du duc de Savoie (1855), provides an account of Emmanuel Philibert, Duke of Savoy, who defeats Henri II in warfare, and then makes peace with him. Not strictly a sequel, as its events run parallel with those in Les Deux Diane, it covers the end of Henri II's reign, such as the battle of Saint-Quentin, the peace of Cateau-Cambrésis, and the king's death following a jousting accident with Gabriel Montgomery. However, many historical characters commonly appear.

Therefore, ostensibly, these novels form the first cycle, or subseries, within Dumas's larger $L a$ Drame de la France. Yet, the issue is more complex. While Dumas likely wrote Ascanio in collaboration with Paul Meurice, the latter is generally recognized as the sole author of Les Deux Diane, even though it is often included in Dumas's complete works and one of the betterknown novels published under his name. Meurice, in need of quick revenue to appear a suitable match for his intended bride's family, allegedly persuaded Dumas to sign Les Deux Diane and publish it for him, since a work by Dumas was more lucrative than one by Meurice. ${ }^{1}$

${ }^{1}$ The literary Goncourt brothers claimed that Dumas read the novel first to determine its suitability to be published under his name. Yet, Paul Foucher, another contemporary, related that when Meurice 
If Les Deux Diane is dismissed from Dumas's Drame de la France on the grounds that he likely did not write it, then Le Page du duc de Savoie, dealing primarily with the period 1555 to 1559, covers much of the same historical and thematic terrain. However, Le Page du duc de Savoie also relates to two later-written novels set in Savoy_La Dame de Volupté (1863) and Les Deux Reines (1864) -and could thus be viewed as part of a different cycle of novels outside $L a$ Drame de la France.

L' Horoscope (1858), which recounts the rein of Henri II's son, François II in 1559, essentially picks up where most of the action in Le Page du duc de Savoie ends. As a result, it could be regarded as complementing Dumas's Ascanio, Les Deux Diane, and Le Page du duc de Savoie, if Les Deux Diane is not excluded, and forming a subseries of four novels because of their common historical setting and characters. However, some recent French literary editions have united Dumas's Ascanio, Les Deux Diane, and L'Horoscope in a single volume as a loose Renaissance trilogy, thereby excluding Le Page du duc de Savoie. ${ }^{1}$

\section{Late Valois Dynasty (circa 1572-1585)}

Dumas's Valois cycle, comprised of La Reine Margot (1845), La Dame de Monsoreau (1845), and Les Quarante-Cinq (1847), has long been viewed as among the "grands romans d'Alexandre Dumas." Dumas wrote these three novels with his best-known literary partner, historian Auguste Maquet, with whom he collaborated during the height of his literary fame as a novelist in the 1840s. ${ }^{2}$ La Reine Margot (1845), which covers French history from 1572 to 1574, details the marriage of Charles IX's sister, Marguerite de Valois, to Henri of Navarre, as well as the St. Bartholomew's Day Massacre. La Dame de Monsoreau and Les Quarante-Cinq relate subsequent events from Henri III's reign over 1578 to 1585 (Natta, 40-60). Due to the prominence these novels hold within Dumas's oeuvre, the lack of other novels covering this period, and the fact that they relate to Dumas's conception of historical progress, these three novels are unchallenged inclusions in La Drame de la France.

\section{Reigns of Louis XIII and XIV (circa 1625-1715)}

Just as Dumas's coverage of French history during the late Valois dynasty is covered in a noted series of novels, so too is his coverage of the reign of Louis XIII and the early reign of his son, Louis XIV. Largely skimming over the rise of the Bourbon dynasty in the personage of Henri IV (who was featured as king of Navarre in La Reine Margot), Dumas jumps to the reign of his son, Louis XIII, during the 1620s in Les Trois Mousquetaires (1844), arguably his most celebrated novel. With Maquet, with whom he had collaborated for Les Trois Mousquetaires, Dumas wrote two well-known sequels, both set during the reign of Louis XIV: Vingt Ans après (1845) and Le Vicomte de Bragelonne (1848-1850). ${ }^{3}$

\footnotetext{
later claimed authorship, Dumas openly supported him, stating that he had not even read it. See: Edmond de Goncourt and Jules de Goncourt, Journal des Goncourt: mémoires de la vie littéraire, ed. Jean-Louis Cabanès, 2 vols. (Paris: H. Champion, 2005-2008), I: 69; Paul Foucher, Les Coulisses du passé (Paris: E. Dentu, 1873), 442.

${ }^{1}$ See: Alexandre Dumas, Les Romans de la Renaissance: Ascanio, Les Deux Diane, and L'Horoscope, ed. Claude Schopp (Paris: Robert Laffont, 2012).

${ }^{2}$ For an overview of their collaboration, see: Gustave Simon, Histoire d'une collaboration: Alexandre Dumas et Auguste Maquet (Paris: Éditions Georges Crès, 1919).

${ }^{3}$ For overview of the duo's composition of the Musketeers cycle, see: Simone Bertière, Dumas et les Mousquetaires: Histoire d'un chef-d'œuvre (Paris: Fallois, 2009).
} 
However, there are three other novels covering historical events that take place between the events of the novels in the Musketeers cycle and feature many of the same historical characters and a similar setting. Including these novels in Dumas's Drame de la France is problematic because they seemingly break up the cycle of Musketeers novels as traditionally conceived. Toward the end of his career, Dumas began writing Le Comte de Moret, or Le Sphinx Rouge (1865-1866), about the last years of Cardinal Richelieu's control over France. Antoine de Bourbon, Comte de Moret (the illegitimate son of Henri IV) is among the novel's primary protagonists. The second novel, La Colombe (1851), represents Dumas's only attempt to write a story solely in the form of imaginary letters. It relates the mysterious disappearance of the Comte de Moret after the battle of Castelnaudary. Despite the difference in style, since $L a$ Colombe picks up events almost exactly where they ended in Le Sphinx Rouge, it is often regarded as its an unofficial "conclusion." As a result, French and English editions typically publish both novels together as a unified entity. ${ }^{1}$ To overcome the challenge of the two often being perceived as outside the Musketeers cycle, some publishers have attempted to bill it as a "sequel" to Les Trois Mousquetaires since the former picks up chronologically where the latter ends and features many of the same historical characters, even though the famous musketeer protagonists themselves do not. Its events also occur well before those of Vingt Ans après. $^{2}$

The third novel, La Guerre des femmes (1844-1846), is focused on the Fronde during Louis XIV's early reign. Vingt Ans après is also set during the interim between Louis XIII's death and Louis XIV's ascension in which Anne of Austria, aided by Cardinal Mazarin, ruled as regent. Consequently, it also features the Fronde. Dumas and Maquet wrote both novels at roughly the same time and the two complement each other in terms of their coverage of historical events. As a result, La Guerre des femmes relates events between Vingt Ans après and Le Vicomte de Bragelonne. Including this novel in Dumas's Drame de la France thus breaks up the traditional Musketeers cycle. Unlike Le Comte de Moret (Le Sphinx Rouge)/La Colombe, it has never been presented as part of this cycle. In terms of historical coverage, the Fronde is also featured in Vingt Ans après. However, La Guerre des femmes is among Dumas and Maquet's stronger efforts and theoretically could be connected through its common historical setting and historical characters.

Finally, Dumas's Sylvandire (1843), his earliest major historical novel depicting the reign of Louis XIV, is focused on the final years of the monarch's long reign. Also written in collaboration with Maquet, this novel helps connect the historical events and themes covered in the Musketeers cycle to his Regency cycle and helps flesh out Dumas's portrait of Louis XIV and his era.

\section{Early Reign of Louis XV (circa 1718-1729)}

Picking up with events shortly after those related in Sylvandire, although written about a year earlier, Le Chevalier d'Harmental (1842) relates the Cellamare Conspiracy against Philippe d'Orléans, who served as regent for the young Louis XV. The novel marked the first

\footnotetext{
${ }^{1}$ See: Alexandre Dumas, Le Sphinx Rouge (Paris: Cherche Midi, 2018); Alexandre Dumas, The Red Sphinx, or The Comte de Moret: A Sequel to The Three Musketeers, trans. Lawrence Ellsworth (New York: Pegasus, 2017).

2 For example, at least one publisher made this claim in the subtitle to a recent English translation of the novel. See: Alexandre Dumas, The Red Sphinx, or The Comte de Moret: A Sequel to The Three Musketeers, trans. Lawrence Ellsworth (New York: Pegasus, 2017).
} 
collaboration between Dumas and Maquet, and the duo followed with a direct sequel, Une Fille du Régent (1844), shortly afterward. The two novels are often known as the Regency cycle. Meanwhile, Olympe de Clèves (1852) picks up with Louis XV's reign almost a decade later during the 1727 to 1729 era. This historical novel, although not customarily part of a series with the previous two, nevertheless helps bridge the long gap in coverage of French history between 1719 and 1770, fleshes out Dumas's portrait of Louis XV and his reign, and since it features a common historical setting and characters, could be regarded as loosely connected to an expanded Regency cycle (as could Sylvandire as well).

\section{French Revolutionary Era (circa 1770-1793)}

Dumas's longest series of novels-known as the Mémoires d'un médecin cycle-focuses on the events leading up to the French Revolution and those of the Revolution itself up to 1793. Along with the Valois cycle and Musketeers cycle, it is arguably among Dumas's most famous group of historical fiction novels. Like these two cycles, Maquet was Dumas's main collaborator (as he was involved with four of the five novels in the Mémoires d'un médecin cycle). Consequently, there is not much debate among Dumas scholars as to whether they should be included in La Drame de la France.

The first novel, Mémoires d'un médecin: Joseph Balsamo (1846-1848), relates the end of Louis XV's reign and the marriage of Marie Antoinette and the future Louis XVI (c. 1770-1774). It is followed by Le Collier de la Reine (1849-1850), focusing on the diamond necklace affair involving Marie Antoinette. Ange Pitou (1853) relates the start of the French Revolution in 1789, while La Comtesse de Charny (1853-1855) covers the events of the French Revolution through Louis XV's execution in 1793. The final novel in the series, Le Chevalier de MaisonRouge (1845), although the first to be written, is set in 1793 and includes the attempted rescue of Marie Antoinette from the Temple (1793).

Dumas wrote several other tales, novels, pseudo-memoirs, and non-fiction books-such as Louis XVI et la Révolution (1850-1851), Le Drame de quatre-vingt-treize (1851-1852), and La Route de Varennes (1860)-which detail events leading up to and during the French Revolution. From this group emerge four major novels outside his Mémoires d'un médecin cycle, none of which have strong cases for inclusion in Dumas's La Drame de La France. The first of them, Le Meneur de loups (1857), is a supernatural novel set in the 1780s in Dumas's hometown of Villers-Cotterêts. The historical material (setting and characters) is not a focus of this novel and including it in Dumas's La Drame de la France would also break up his Mémoires d'un médecin cycle. Moreover, it does not advance the overarching theoretical framework uniting Dumas's novel sequence.

The next, Création et Rédemption (1872), is a posthumously published novel relating the adventures of a doctor and a young girl during the onset of the French Revolution (circa 17851794) It consists of two parts: "Le Docteur Mysterieux" and "La Fille du Marquis." Including it in Dumas's La Drame de la France would break up his Mémoires d'un médecin cycle and does not necessary add anything new by way of coverage of historical events or further Dumas's views on French history that unite his novel sequence.

The remaining two novels can perhaps be seen as falling more in line with Dumas's works in which he collaborated with others (or was credited with collaborating with others) on real or 
quasi-fictitious memoirs rather than his works of historical fiction. ${ }^{1}$ The first, Ingénue (1854), focuses on the events leading to the French Revolution (circa 1788-1793). It is allegedly a retelling of an autobiographical novel by eighteenth-century writer Nicolas-Edme Restif. The second, Le Volontaire de '92 (1862), again focuses on events leading up to the French Revolution (circa 1788-1793). In 1856, Dumas met a veteran of Napoléon's army, who allegedly gave him a memoir detailing his experiences in the French Revolution. The book purports to be this memoir.

Le Capitaine Paul (1838) is not considered in these discussions, as it features American Revolutionary War hero John Paul Jones as its protagonist and does not readily relate to his overarching views on French history. However, Dumas gives Jones a French origin and most of the novel is set in France during Louis XVI's reign.

\section{Rise of Napoléon and the First French Empire (circa 1793-1815)}

Dumas's primary historical fiction novels set during the rise of Napoléon and the First French Empire are those comprising his Sainte-Hermine cycle, which were generally written toward the end of his life and career. While the novels in his earlier series were generally written during the 1840s and 1850s, Dumas did not start his Sainte-Hermine cycle until the late 1850s. As a result, this is the one cycle in which Dumas in all probability did intend at the time of its composition for it to comprise part of his larger La Drame de la France. The cycle begins chronologically with Les Blancs et les Bleus (1867-1868), which continues with the historical events that unfolded in his earlier Mémoires d'un médecin cycle. Consequently, it covers the latter portion of the French Revolution (circa 1793-1799), including the Reign of Terror, the Convention, the Directory, and, most significantly for the future of the series, the rise of Napoléon. The subsequent novel, Les Compagnons de Jéhu (1857), focuses on such historical events in 1799 to 1800 as Napoléon's tenure as First Consul, royalist resistance to Napoléon, and ultimately his consolidation of power. The third novel in the cycle, Le Chevalier de SainteHermine (2005), is set during the rise of the Napoleonic Empire (1800-1809). It remained incomplete at the time of Dumas's death. However, during the early twenty-first century, Claude Schopp collected and completed it, thereby enabling it to be published in novel form.

Before the completion of Le Chevalier de Sainte-Hermine, there remained a gap in terms of the coverage of the First French Empire, as the events of Les Compagnons de Jéhu ended in 1800, before Napoléon became emperor, and the only other novel Dumas wrote relating to the Napoleonic era was Le Capitaine Richard (1858), which focuses on the end of the First French Empire during the years 1809 to 1815 . Le Capitaine Richard, although not typically a part of the Sainte-Hermine cycle, provides a logical continuation of the historical events as they left off in Le Chevalier de Sainte-Hermine and serves as a bridge to take Dumas's La Drame de la France to the Restoration era. It provides much attention to Napoléon's retreat from Moscow and largely skips over Napoléon's 100 Days and Waterloo, but Napoléon's subsequent exile to St. Helena is covered in a flash-forward.

However, although Le Chevalier de Sainte-Hermine ends the Sainte-Hermine cycle as started in Dumas's lifetime, Claude Schopp used material from Dumas as the basis for Le Salut de l'Empire (2008). Billed as a novel by Dumas and Schopp, it covers the end of the First French Empire

\footnotetext{
1 Other such books include La Vendée et Madame (1833), Mémoires de J.-F. Talma (1850), Un Gil Blas en Californie (1852), Une Vie d'artiste: Aventures et tribulations d'un comédien (1854), Le Journal de Madame Giovanni (1856), Mémoires d'un policeman (1859), Mémoires de Garibaldi (1860), and Un Cadet de famille (1860).
} 
from 1808 to 1815, including Napoléon's retreat from Moscow, the Battle of Leipzig, Napoléon's exile to Elba, the Restoration, Napoléon's 100 Days, and Waterloo. This historical novel is intended as a more definitive conclusion to Dumas's Sainte-Hermine cycle. However, for Dumas purists, prior to the posthumous co-authored publication of Le Salut de l'Empire in the twenty-first century, Le Capitaine Richard was Dumas's only historical novel to cover the end of Napoléon and "conclude" the Saint-Hermine cycle. The historical events in both novels run parallel to each other, suggesting only one is needed to conclude the cycle.

The only other major historical novel set during the era of Napoléon worth considering for inclusion in La Drame de la France is Conscience l'innocent (1853), which focuses on the exploits of a conscript in the years 1810 to 1815. The historical period is covered elsewhere, and historical figures, events, and themes play a lesser role in this novel than they do in others.

\section{Restoration Era and July Monarchy}

As the back story in Dumas and Maquet's celebrated Le Comte de Monte Cristo (1845-1846) covers Napoléon's exile on Elba, his brief return during the 100 Days, and the return of the Bourbon monarchy during the Restoration, and the main story takes place in the 1830s during the subsequent July Monarchy, many, like Schopp, have viewed Le Comte de Monte Cristo as bridging the events that unfolded in the Sainte-Hermine series with Dumas's present and thus serves as the finale to his Drame de la France. Moreover, the Count of Monte Cristo emerges as the hero of Dumas's conception of modern society. ${ }^{1}$

As Dumas's La Drame de la France has been viewed by some literary critics as a precursor to Balzac's La Comédie humaine, which is set during the Restoration (1815-1830) and July Monarchy (1830-1848), his historical novels set during this era have been largely overlooked. However, there are three novels Dumas wrote set in the Restoration era and July Monarchy that relate events occurring primarily between the backstory and main story contained within the Le Comte de Monte Cristo that merit consideration for inclusion in La Drame de la France. The first of these is Georges (1843), written with Félicien Mallefille. A short backstory connects the novel to the Napoleonic era (circa 1810), while the novel's main story unfolds in 1824. As this novel is set in the French colonies, it is not usually perceived as part of Dumas's La Drame de la France. However, if one expands the concept of "France" to extend beyond the metropole, it becomes a possibility. Moreover, since it concerns the issues of race and slavery, it has become one of Dumas's most studied and significant novels. ${ }^{2}$ However, it also includes his

\footnotetext{
1 On this point, see: Anne-Marie Callet-Bianco, "De Monte-Cristo aux Mohicans: l'affirmation du sentiment républicain," In Dumas, une lecture de l'Histoire, 189-208; David F. Bell, "Velocities: Precision, Overload (Dumas)," in Real Time: Accelerating Narrative from Balzac to Zola (Urbana: University of Illinois Press, 2004), 103-130.

2 Examples include: Molly Krueger Enz, "The Mulatto as Island and the Island as Mulatto in Alexandre Dumas's Georges," The French Review 80, 2 (December 2006): 383-394; Amédée Nagapen, Esclavage et marronnage dans le roman Georges d'Alexandre Dumas l'apport des chronicles de J.G. Milbert (Mauritius: University of Mauritius, 2005); Molly Krueger Enz, "White Negroes, Nothing More': The Ambiguous Role of the 'Mulatto' in Alexandre Dumas's Georges," in The Black Musketeer, 91-106; Claudie Bernard, "Georges, or the 'Mixed-Blood' Settles Scores," ," in The Black Musketeer, 127-159; Hilary A. Heffley, "Conquering Nature: Elements of Early Nineteenth-Century Ethnology in Alexandre Dumas's Georges," in Alexandre Dumas as a French Symbol since 1870, 119-139; Virginia Payne Dow, "Alexandre Dumas: Hidden in His Doppelgänger Paradigm," in Alexandre Dumas as a French Symbol since 1870, 141-174.
} 
novel sequence's larger themes relating to merit based on ability rather than birth and republican sentiments.

The next novel to be considered is Les Mohicans de Paris (1854-1859), set between 1820 to 1830 during the Restoration. The novel, not typically regarded as one of Dumas's historical romances, has become widely praised as a pioneer of the detective novel. ${ }^{1}$ However, it also deals with all classes and characters of Paris at the time, thereby providing an illuminating study of the Restoration arguably on par with those in the novels in Balzac's La Comédie humaine, and allows Dumas to reflect on the developing epoch of private property that he sees as developing in the post-French Revolutionary era. Further, without a novel such as Les Mohicans de Paris to bridge events between the end of Napoléon and the demise of the July Monarchy, it is more difficult to include in La Drame de la France the final novel to be considered, Les Louves de Machecoul (1859).

Although Les Louves de Machecoul relates episodes from 1793 to 1843, its focus is on the July Revolution of 1830 and especially the subsequent royalist uprising in the Vendée led by the Duchesse de Berry in 1832 to place her son on the throne. In terms of coverage of historical events, it addresses and fleshes out the transition from the Restoration to the July Monarchy. Moreover, this historical novel emphasizes many of the overarching themes within Dumas's conception of history and his Drame de la France. Dumas constructs his tale based on the Duchesse's failed uprising to represent allegorically a broader struggle between Counterrevolutionary and Revolutionary France that came to a head in the post-revolutionary era. In Dumas's view, the fate of the uprising determined the fate of the nation. Thus, to Dumas, the 1832 defeat of the Duchesse and her Legitimist supporters marked a decisive turning point on France's road to realizing its republican destiny as outlined during the French Revolution. The narrative thus presents a strong republican polemic to argue unmistakably that France is destined to be a republic and is conceptually one of Dumas's most significant historical novels. ${ }^{2}$

\section{Conclusion}

Dumas's historical romances may or may not have been written intentionally from the beginning as forming a larger collective known as La Drame de la France, first declared by the writer in the 1850s. Although the scope of Dumas's La Drame de la France is undefined, French literary scholars have generally agreed on the inclusion of his smaller cycles of historical romances as being crucial components of it. Moreover, Dumas's early work, Gaule et France, has been cited as the theoretical foundation for much of the thematic threads regarding progress and historical change in these novels. However, the vastness of Dumas's body of work leads to the possibility of various other inclusions to La Drame de La France. Agreeing on a full scope of novels for this collective series is necessary to advance studies of Dumas in this area. By briefly examining these other possibilities, there are 31 novels that have a strong case for inclusion in La Drame de la France, which can be seen in broader nineteenth-century French literature as complementing Balzac's La Comédie humaine and Zola's Les Rougon-Macquart. Such defined series have been subject to many studies, but without the establishment of which books comprise Dumas's La Drame de la France, to study Dumas's work in a similar fashion,

\footnotetext{
${ }^{1}$ See: Nicolas Gauthier, Lire la ville, dire le crime: mise en scène de la criminalité dans les mystères urbains de 1840 à 1860 (Limoges: Presses universitaires de Limoges, 2018).

2 For an elaboration on this point, see: Eric Martone, "The Last Vendée: The Duchesse de Berry, Legitimist Propaganda, and Alexandre Dumas," in Royalists, Radicals, and les Misérables: France in 1832, ed. Eric Martone (Newcastle-upon-Tyne: Cambridge Scholars, 2013), 13-73.
} 
or compare it to other nineteenth-century literacy series, is not possible. ${ }^{1}$ As a result, there have been no comparable monographs to date published on Dumas's La Drame de la France.

\section{References}

[1] Alexander, J.H. Walter Scott's Books: Reading the Waverley Novels. New York: Routledge, 2017.

[2] Anselmini, Julie, ed. Dumas Critique. Presses universitaires de Limoges, 2013.

[3] Arrous, Michel, ed. Dumas, une lecture de l'histoire. Maisonneuve and Larose, 2003.

[4] Audebrand, Philibert. Alexandre Dumas à la Maison d'or: Souvenirs de la vie littéraire. Calmann Lévy, 1888.

[5] Bell, A. Craig. Alexandre Dumas: A Biography and Study. Cassell, 1950.

[6] Bell, David F. Real Time: Accelerating Narrative from Balzac to Zola. University of Illinois Press, 2004.

[7] Bernard, Claudie. "Georges, or the 'Mixed-Blood' Settles Scores." In The Black Musketeer: Reevaluating Alexandre Dumas within the Francophone World. ed. Eric Martone. Cambridge Scholars, 2011. pp. 127-159.

[8] Bertière, Simone. Dumas et les Mousquetaires: Histoire d'un chef-d'œuvre. Fallois, 2009.

[9] Brunetière, Ferdinand. Histoire de la littérature française. Librairie Delagrave, 1917.

[10] Bury, Henri Blaze de. Alexandre Dumas, sa vie, son temps, son œuvre. Calmann Lévy, 1885.

[11] Callet-Bianco, Anne-Marie. "De Monte-Cristo aux Mohicans: l'affirmation du sentiment républicain." In Dumas, une lecture de l'Histoire, ed. Michel Arrous. Maisonneuve and Larose, 2003. pp. 189-208.

[12] Canfield, Arthur. The Reappearing Characters in Balzac's Comédie Humaine. Westport, CT: Praeger, 1977.

[13] Déruelle, Aude. “Dumas et Balzac." In L'Herne: Dumas. eds. Sylvain Ledda and Claude Schopp. Paris: L'Herne, 2020. pp. 117-118.

[14] Dickinson, Linzy Erika. Theatre In Balzac's La Comédie Humaine. Leiden: Brill Rodopi, 2000.

[15] Dow, Virginia Payne. "Alexandre Dumas: Hidden in His Doppelgänger Paradigm.” In Alexandre Dumas as a French Symbol since 1870: All for One and One for All in a Global France. ed. Eric Martone. Cambridge Scholars, 2020. pp. 141-174.

\footnotetext{
1 Examples of such studies for La Comédie humaine include: Arthur Canfield, The Reappearing Characters in Balzac's Comédie Humaine (Westport, CT: Praeger, 1977); James Mileham, The Conspiracy Novel: Structure and Metaphor in Balzac's Comédie Humaine (Lexington, KY: French Forum, 1982); Melissa Marcus, The Representation of Mesmerism in Honoré de Balzac's La Comédie humaine (New York: Peter Lang, 1995); Linzy Erika Dickinson, Theatre In Balzac's La Comédie Humaine (Leiden: Brill Rodopi, 2000); Diana Knight, Balzac and the Model of Painting: Artist Stories in La Comédie Humaine (New York: Routledge, 2007). Examples of such studies for Les Rougon-Macquart include: J.G. Patterson, A Zola Dictionary; The Characters of the Rougon-Macquart Novels of Émile Zola (New York: George Routledge and Sons, 1912); Lewis Kamm, The Object in Zola's Rougon-Macquart (Madrid: José Porrúa Turanzas, 1978); Brian Nelson, Zola and the Bourgeoisie: A Study of Themes and Techniques in Les Rougon-Macquart (London: Palgrave Macmillan, 1983); Philippe Hamon, Le Personnel du roman: Le systeme des personnages dans les Rougon-Macquart d' Émile Zola (Geneva: Librairie Droz, 1998); Julie Pihard, Émile Zola et le roman expérimental: Les Rougon-Macquart ou la parfaite illustration du naturalisme (Brussels: 50Minutes, 2015).
} 
[16] Dumas, Alexandre. Les Compagnons de Jéhu. New ed. 3 vols. Calmann Lévy, 1887.

[17] -----, Alexandre. The Companions of Jehu. Trans. New York: P.F. Collier and Son, n.d.

[18] -----, Alexandre. Gaule et France. Auguste Auffray, 1833.

[19] -----, Alexandre. Théâtre complet: Ivanhoé. Ed. Fernande Bassan. Paris: Lettres Moderne Minard, 1974.

[20] -----, Alexandre. The Progress of Democracy; Illustrated in the History of Gaul and France. trans. J. and H. G. Langley, 1841. Reprint; University Press of the Pacific, 2002.

[21] -----, Alexandre. The Red Sphinx, or The Comte de Moret: A Sequel to The Three Musketeers. trans. Lawrence Ellsworth. Pegasus, 2017.

[22] -----, Alexandre. Les Romans de la Renaissance: Ascanio, Les Deux Diane, and L'Horoscope. ed. Claude Schopp. Robert Laffont, 2012.

[23] -----, Alexandre. Le Sphinx Rouge. Cherche Midi, 2018.

[24] Durand, Pascal, and Mombert, Sarah, eds. Entre presse et littérature: Le Mousquetaire, journal de M. Alexandre Dumas. Bibliothèque de la Faculté de Philosophie et Lettres, Diffusion Droz, 2009.

[25] Enz, Molly Krueger. "The Mulatto as Island and the Island as Mulatto in Alexandre Dumas's Georges." The French Review, vol. 80, no. 2, 2006, pp. 383-394.

[26] Enz, Molly Krueger. "White Negroes, Nothing More': The Ambiguous Role of the 'Mulatto' in Alexandre Dumas's Georges.” In The Black Musketeer: Reevaluating Alexandre Dumas within the Francophone World. Ed. Eric Martone. Cambridge Scholars, 2011. pp. 91-106.

[27] Foucher, Paul. Les Coulisses du passé. E. Dentu, 1873.

[28] Gauthier, Nicolas. Lire la ville, dire le crime: mise en scène de la criminalité dans les mystères urbains de 1840 à 1860. Presses universitaires de Limoges, 2018.

[29] Goncourt, Edmond de, and Goncourt, Jules de. Journal des Goncourt: mémoires de la vie littéraire. ed. Jean-Louis Cabanès. 2 vols. H. Champion, 2005-2008.

[30] Grivel, Charles, ed. Les Vies parallèles d'Alexandre Dumas. Presses Universitaires du Septentrion/Revue des Sciences humaines, 2008.

[31] Hamon, Philippe. Le Personnel du roman: Le système des personnages dans les Rougon-Macquart d'Émile Zola. Geneva: Librairie Droz, 1998.

[32] Heffley, Hilary A. "Conquering Nature: Elements of Early Nineteenth-Century Ethnology in Alexandre Dumas's Georges." In Alexandre Dumas as a French Symbol since 1870: All for One and One for All in a Global France. ed. Eric Martone. Cambridge Scholars, 2020. pp. 119-139.

[33] Kamm, Lewis. The Object in Zola's Rougon-Macquart. Madrid: José Porrúa Turanzas, 1978.

[34] Knight, Diana. Balzac and the Model of Painting: Artist Stories in La Comédie Humaine. New York: Routledge, 2007.

[35] Marcus, Melissa. The Representation of Mesmerism in Honoré de Balzac's La Comédie humaine. New York: Peter Lang, 1995.

[36] Martone, Eric, ed. Alexandre Dumas as a French Symbol since 1870: All for One and One for All in a Global France. Cambridge Scholars, 2020.

[37] Martone, Eric. "All for One and One for All: Recasting Alexandre Dumas as a Popular Educator in France during the New Imperialism." Global Education Review, vol. 6, no. 4, 2019, pp. 50-79. 
[38] Martone, Eric, ed. The Black Musketeer: Reevaluating Alexandre Dumas within the Francophone World. Cambridge Scholars, 2011.

[39] Martone, Eric. Finding Monte Cristo: Alexandre Dumas and the French Atlantic World. McFarland, 2018.

[40] Martone, Eric. "The Last Vendée: The Duchesse de Berry, Legitimist Propaganda, and Alexandre Dumas." In Royalists, Radicals, and les Misérables: France in 1832, ed. Eric Martone. Cambridge Scholars, 2013. pp. 13-73.

[41] Massol, Chantal, ed. Stendhal, Balzac, Dumas: Un récit romantique ? Presses Universitaires du Mirail, 2006.

[42] Maurois, André. The Titans: A Three-Generation Biography of the Dumas. trans. Gerard Hopkins. Harper and Brothers, 1957.

[43] Mileham, James. The Conspiracy Novel: Structure and Metaphor in Balzac's Comédie Humaine. Lexington, KY: French Forum, 1982.

[44] Nagapen, Amédée. Esclavage et marronnage dans le roman Georges d'Alexandre Dumas l'apport des chroniques de J.G. Milbert. University of Mauritius, 2005.

[45] Natta, Marie-Christine. "La représentation du favori du prince dans La Dame de Montsoreau." In Dumas, une lecture de l'histoire, ed. Michel Arrous. Maisonneuve and Larose, 2003. pp. 40-60.

[46] Nelson, Brian. Zola and the Bourgeoisie: A Study of Themes and Techniques in Les Rougon-Macquart. London: Palgrave Macmillan, 1983.

[47] Patterson, J.G. A Zola Dictionary: The Characters of the Rougon-Macquart Novels of Émile Zola. New York: George Routledge and Sons, 1912.

[48] Pellissier, Georges. "Alexandre Dumas père par Hippolyte Parigot." Revue universelle: année 1902. Librairie Larousse, n.d.

[49] Peng, Youjun. La nation chez Alexandre Dumas. Paris: L'Harmattan, 2003.

[50] Petit-Rasselle, Roxane. "From the Literary Myth to the Lieu de Mémoire-Alexandre Dumas and French National Identity(ies)." In Alexandre Dumas as a French Symbol since 1870: All for One and One for All in a Global France, ed. Eric Martone. Cambridge Scholars, 2020. pp. 89-117.

[51] Pihard, Julie. Émile Zola et le roman expérimental: Les Rougon-Macquart ou la parfaite illustration du naturalisme. Brussels: 50Minutes, 2015.

[52] Robin, Charles. Galerie des Gens de Lettres du dix-neuvième siècle. Victor Lecou, 1848.

[53] Santa, Angels, and Lafarga, Francisco, eds. Alexandre Dumas y Victor Hugo: Viaje de los textos y textos de viaje. Pagès Editors, 2006.

[54] Schopp, Claude. Dictionnaire Dumas. Paris: CNRS Éditions, 2010.

[55] Schopp, Claude. "Le fil de l'Histoire." Le Figaro (hors-série): Alexandre Dumas, Au galop des mousquetaires, 2002.

[56] Schopp, Claude. "Le Testament perdu." In Alexandre Dumas, Le Chevalier de SainteHermine. ed. Claude Schopp. Phébus, 2005.

[57] Simon, Gustave. Histoire d'une collaboration: Alexandre Dumas et Auguste Maquet. Éditions Georges Crès, 1919.

[58] Trench-Bonett, Dorothy. "Alexandre Dumas: Black French Writer." In Alexandre Dumas, Charles VII at the Home of His Vassals. trans. Dorothy Trench-Bonett. Noble Press, 1991.

[59] Tulard, Jean. Alexandre Dumas, 1802-1870. Paris: Figures et plumes, 2008. 